\title{
Tea Plantations in the Darjeeling Hills Geo-Ecological Impact and Livelihood Implications
}

Lalit P. Tirkey and Padam Nepal

Lalit P. Tirkey

Padam Nepal

\begin{abstract}
The geo-ecological stability of a place has an important role in contributing to the livelihood security of its people. A disturbance to the geo-ecology of a region jeopardizes the livelihood resources of the population and creates pressures for livelihood security. Human interventions in the form of destruction of forests and degradation of land significantly alter the geo-ecology of a region. Moreover, interventions with forests result in several other forms of degradations of the geo-ecology of a region. In the light of this understanding, the present study evaluates the impact of tea plantations on the geo-ecology of Darjeeling Hills, Inia and the consequent impact on the livelihood security of the people in the region.
\end{abstract}

Key words: Land resources, land use pattern, livelihood security, geo-ecology, deforestation, landslides, soil erosion, tea, India

\section{Background and Context}

$\mathbf{G}$ eo-ecological stability of a place has an important role in contributing to the livelihood security of its people. A disturbance to the geo-ecology of a region jeopardizes the livelihood resources of the population and creates pressures for livelihood security. Human interventions in the form of destruction of forests and degradation of land significantly alter the geo-ecology of a region. Moreover, interventions with forests result in several other forms of degradations. In the light of this understanding, the present paper evaluates the impact of tea plantations on the geo-ecology of Darjeeling Hills and its consequent impact on the livelihood security of the people in the region.

Commercial tea production has been the mainstay of livelihoods and economy in the Darjeeling Hills for over 150 years. Situated in the Himalayan front ranges in West Bengal, India, the Darjeeling Hills were transformed in the mid-19th century from a sparsely populated, forested landscape to one dominated by extensive tea estates, linked roads, railway, a major town and many estatebased villages populated by workers. The area, with an elevation range of 800 to $2600 \mathrm{~m} /$ asl, copious and reliable precipitation (3000mm/annum), steep slopes and a diversity of micro-environments proved suitable for the cultivation of tea on plantation basis.

Since its beginning, the tea industry has played a pivotal role in the socio-economic lives of people of the region by providing direct employment to thousands of households and ancillary jobs to many more thousands in chest-tea, plywood, tea packaging and other tearelated trades (Choudhari 1978; Sarkar and Lama 1986). In the last three-four decades, however, the livelihood of the large, dependent population has been threatened. The gradual decline of the Darjeeling tea industry from strong international competition, increasing production and labor costs, and declining productivity, and other factors, have affected the sustainable livelihoods of plantation workers (Moitra 1991). As a result, some estates have closed. Moreover, the rapid expansion of tea plantations in the high altitudes has had adverse effect on the land and forest resources of the region.

The environmental degradation of this region initially began with the cultivation of tea on high slopes covering about 18,00o hectares of land (O'Malley 1907; Chaudhuri 1978; Starkel and Basu 2000). The expansion of tea plantations from just one tea estate in 1856, 39 in 1866,113 in 1874 and 186 by 1905 apparently led to large-scale forest clearing, resulting in landslides, soil erosion, loss of wildlife and biodiversity (O’Malley 1907; Starkel and Basu 2000). Moreover, the use of pesticides, herbicides and fertilizers have caused contamination of rivers/streams and degradation of land (Raina 1992; Chettri 2004). With the gradual increase in population, unemployment in tea plantations multiplied, which compelled people to search for alternative livelihoods by often tapping forest products, encroaching forest and slope land; thereby, further damaging the local ecology and degrading the environment (Bhadra 1992). In addition, the unchecked deforestation, faulty landuse practices, settlement of burgeoning population on mountain slopes, unregulated construction of roads and encroachment of forest lands led to radical transformation of the geo-ecological conditions in the Darjeeling. The job uncertainty and potential loss of livelihood in the tea plantations is leading to a new phenomenon of outmigration to urban centres, resulting in construction of new buildings on slopes; thereby creating space shortage, land pressure, water scarcity and drainage problems in the region (Sarkar and Lama 1986).

\section{Study Area and Setting Singell Tea Estate}

Established in 1870 by a British Planter, James White, this tea estate started operating as Hor \& Miller Co., and continued until 1960 before the ownership was passed on to Indian owner, Rampuria Company. This garden has always been a conventional type, with a command-and-control management system. In this type of plantation tea workers possess no ownership rights; they are merely daily wage earners with no control over plantation assets or participation in decision-making 
processes (ICIMOD 2003). The garden has experienced frequent lockouts due to financial crunch and labor unrest including Government- take over on 21 March 1986. This notwithstanding, this tea estate continued to limp financially and so, in mid-1980s it was declared a "sick garden" during a period marred by garden mismanagement and political unrest. December 1999 signalled the beginning of a new era when Tea Promoters of India Pvt. Ltd (TPI) assumed the ownership of Singell. With the environmentally-friendly and socioeconomically stable management at the helm, the plantation was transformed into a healthy garden.

\section{Mineral Spring Tea Estate}

Situated about $18 \mathrm{kms}$ north-east of Darjeeling town this garden was completely closed down in 1961. After the closure, the workers were compelled to seek alternative livelihoods by working on neighboring tea plantations or by relying on forest products for their immediate survival. In the absence of land ownership, some families made their living on road construction or sold 'hand-made tea' for very low prices. In the subsequent years, workers 'grabbed' parcels of tea plantation land and started subsistence cultivation by uprooting tea bushes. As the yield from the fields proved to be very poor, they started felling forest trees and selling them as timber, firewood and charcoal (Rai and Sarkar 1986). Therefore, in the period between the late- 1960 s and the mid-1980s, forest cover around the settlements declined considerably, contributing to soil erosion, landslides, decline of the water table and destruction of wildlife habitats (RCDC 1996). After the closure, according to the National Social Service-Survey Report (1971), the average annual income of the household in Mineral Spring Tea Estate fell to mere Rupees 600 ( 1 Rupees $=1 / 45$ US $\$$ ). In the 1990 s the garden was transformed from a tea estate-village into a revenue-village cultivating cash crops including tea. In the new system, the ownership and management pattern became co-operative in nature.

\section{Geo-Topographical Features of the Study Area Vegetation and forestry}

In the Singell Tea Estate, dense forest cover is conspicuous by its absence. The unhindered tree felling by plantation people as well as by different managements for firewood and sale of timber is responsible for sparse forest trees in the area.

The forest adjacent to Mineral Spring is relatively dense and intact, mainly because they have been protected by the Sinchell Wildlife Sanctuary under the supervision of Wildlife Division. However, a dense tree cover can be seen in and around the Mineral Spring, too. This is due to various factors.

Firstly, since the residents of Mineral Spring were denied access to forest, they were compelled to plant trees in their own fields leading to dense vegetation in the area since the 1990 s. A key informant puts it well: "There were some factors that led to the kind of reforestation measures being taken by the people at household level. Firstly, the forest was very far for accessing firewood, and secondly, the areas after being declared 'protected forests' became inaccessible to the public. This compelled some households to plant Oatis, Malata, Narket reed, Cyris and other fast growing trees to meet the demand for firewood and fodder from their own fields. As every household started planting trees around their houses, the entire area resembled a dense forest."

\section{Land resources and land use pattern}

Accessible fertile land in the Darjeeling Himalaya is scarce; available land is covered with biologically diverse vegetation. In the entire Darjeeling Hills about $38 \%$ of the area is occupied by forest cover, $18 \%$ by tea plantations, $2 \%$ by cinchona plantation, and the rest of the land (42\%) has been used as Khasmahal for human settlement, waste land and stream/rivers etc. (Fareedi, Khanna and Lepcha 2000). This, however, is gradually changing due to population growth and increasing developmental activities in region.

In the Singell Tea Estate, 282 hectares (53\%) of allotted land is used for the tea cultivation leaving $47 \%$ land for forest cover, human settlement and Khasmahal. Moreover, encroachment of peripheral tea garden land along the road has changed the land use pattern around Singell Tea Estate.

In the Mineral Spring area, the land use pattern has undergone dramatic changes-from the most extensive land use for tea cultivation 50 years ago to an alarming rate of deforestation in the late 1960's to 1980's following closure of tea estate and planting of trees at household level. In recent years this has resulted in the dense forest cover. Planting of fast growing trees has not only changed the land use pattern but has also helped in stabilizing the land; thereby, preventing and reducing landslides and erosion.

\section{Water resources}

The two study areas are rich in water resources due to the presence of many perennially flowing streams and natural springs. The monsoon precipitation from mid-May until late September supplies the water in the region for about seven months. Numerous mountain streams (jhoras) also serve as sources of water in this region for domestic use and irrigation purposes. Mineral Spring has two perennially running streams, while Singell Tea Estate has two mountain streams-Hushel Khola and Kharen Jhora. They serve as excellent sources of irrigation for the tea plantation. The region is also blessed with many natural springs (dharas) from which people draw potable water.

\section{Geo-Ecological Impact of Plantations Loss of forest cover}

Deforestation took place in the 19th century when many trees were cleared to begin tea cultivation. Research by Ives and Messerli (1989), Sarkar and Lama (1986), and 
Schikhoff (1995), provide evidence of problems caused by deforestation in the Himalaya in the form of loss of biodiversity, wildlife, gradual drying up of springs/ channels and problems of landslides/soil-erosion. This early deforestation represents one form of degradation.

Evidence of another form of environmental damage is provided by Schickhoff (1995), Tiwari (2000), Nusser (2000), Gardner (2003) and Kaniyal (2003), and others. Competition for food, fuel and other resources intensifies due to rapid population growth, often causing humans to turn to destructive practices. In the case of tea plantations, the forests were replaced by tea bushes, which, at least, have some degree of soil stabilizing influence.

Findings show that both study areas witnessed two phases of deforestation: first in the mid-19th century, when forested areas were extensively cleared during the creation of tea plantations. Tea bushes buffered the negative environmental effects, however, especially local landslides/soil erosion that occurred as a result of deforestation. Secondly, episodes of deforestation in both tea estates followed the temporary or complete closure as a result of out-of-work laborers engaging in substantial felling of forest trees. The cumulative effect of these past activities resulted in the loss of biodiversity, wildlife, and gradual decline of water table (Sarkar and Lama 1986).

In a more prominent way the cumulative effects of deforestation weremanifestedin theland sliding problems in the entire Darjeeling area that was accentuated in 1950 and 1968 under the impact of heavy rainfall (Starkel 1993; Rai and Sarkar 1986). A major finding in both study areas is the notable reduction in the incidence of deforestation in recent years. This remarkable result is due to various factors: at Mineral Spring, due to the Forest Department's sanctions against tree felling and afforestation measures at household level; whereas at Singell Tea Estate, due to the introduction of liquefied petroleum gas (LPG) as an alternative fuel for cooking, and also the imposition of penalties for tree-felling by the plantation management.

\section{Landslides/soil-erosion}

The Darjeeling Hills area, like other parts of the Himalaya, is susceptible to landslides and other erosional processes. According to earlier studies, the presence of sandstones and siltstones of the Darjeeling gneisses has always been susceptible to land sliding and other natural hazards (Banerjee 1982). This explains the widespread destructive landslides at certain periods during the past 150 years (Starkel and Basu 2000). Due to steep slope and large-scale deforestation in the past, many small and large landslides, mudslides, rock fall, and soil erosion have occurred throughout the Himalaya (Sarkar and Lama 1986; Ives and Messerli 1989; Pant and Khanduri 1998).

Rapid expansion of tea plantations in the preIndependence era and deforestation problems during 'tea estate closures' further aggravated the ecological fragility of the area in the form of weakening of slopes, soil erosion and land sliding and other forms of environmental degradation (Chada 1990). While many consider heavy rain as the major trigger factor for these landslips, it is the human interference through faulty land-use practices and other developmental activities that have aggravated the situation (Basu 1979). In some areas these activities exacerbated already existing landslides and erosion problems initiated in the past by expansive cultivation of tea after clearance of forest, uprooting of vegetation, earth cutting, blasting of rocks and construction of numerous small roads (O’Malley 1907; Choudhari 1978).

Instances of landslides have reduced considerably in both the study areas. Today, landslides are 'small' in magnitude, causing no significant damage to people or place. Landslides and soil erosion in both study areas are reduced due to the presence of dense tree cover, proper terrace agricultural practices (as seen in Mineral Spring), and to a proper drainage system (as seen in Singell). There are no adequate data to suggest that clearing of forests for plantations (tea/cinchona) have caused large-scale landslides. There are only some recorded documents showing landslides seriously damaging tea plantations (Starkel and Basu 2000), except the 1968 landsides when "more land was lost in the tea plantation areas as compared to land in the forested areas" (Starkel 1993). In fact, tea bushes seem to have played a significant role in stabilizing some local landslides and soil-erosion. In other words, neither the existence of tea plants nor the replantation measures has accentuated landslides. Instead, study shows that mature tea plants have stabilized the land and have prevented minor landslides. There are, however, cases of soil erosion that occur during the uprooting of tea plants or during re-plantation measures when soil erodes from the slopes.

Notwithstanding these improvements, recent road constructions linked to development in both cases have caused landslides and soil erosion. As a matter of fact, from the onset of the tea industry in Darjeeling, road construction on tea estates has caused landslides and soil erosion problems due to the removal of soil, rock, and uprooting of vegetation (Roy 1965; Choudhari 1978).

Similar research conducted in the mountain areas of North Bengal has reported increased landslides due to road construction and also along existing roads during heavy rains (Sarkar and Lama 1986; Starkel and Basu 2000). Yet, people overlook the fact that the development of a hill area comes at the expense of landslides and soil erosion and subsequent land degradation (Heimsath 2000). In the two plantations under study, residents argue in favor of roads since they usher in economic development. People need to remember that road construction, although providing a measure of development, involves activities that often lead to the destabilization of hill slopes that, in turn, aggravates soil-erosion and landslides. With respect to the two cases studied, however, the impacts of landslides have been, and continue to be, limited. On the other hand, road constructions and other developments have either 
initiated landslides/soil-erosion or have aggravated geoecological problems.

\section{Receding water levels and contaminating water sources}

While the Darjeeling Hills is rich in water resources, there is a near-complete dependence on monsoon rainfall. Besides, for lack of proper water storage devices, water shortage becomes more acute after midSeptember. And due to leakage of water through supply lines (not to mention drying up of many feeding springs) the Darjeeling Hills experiences serious water scarcity (Nepal 2011). To add to this is the water over-utilization by burgeoning local population; this worsens during peak tourist season. According to some records, about 30 natural springs originated in the hills of Darjeeling in the past, but they have been reduced to 24 springs in the catchments area. When water level declines, people tend to use the same water sources for irrigation, cattle feeding and domestic purposes. Extensive use of water for different purposes results in receding of water and contamination of water bodies. In the Singell tea estate, the extensive use of DDT and other pesticides has caused the contamination of natural springs and of surface and ground water. Consequently, under the strict regulation of State Health Department, the management has to purify the water before distributing it to 'labor colonies'. Mineral Spring has smaller streams and springs, but they, too, get polluted during dry season due to short supply, increasing human settlements, and agricultural activities.

\section{Implications for Livelihood Livelihood situations}

The third objective of the study involved a description, evaluation and explanation of the impact of tea plantations on the social and economic situation of plantation communities. A key conclusion of this study is that tea plantations are unable to provide sustainable livelihoods to plantation communities in the same ways as they once did. Generally, the main livelihood source of the people in the Himalaya is obtained from land and forest (Sinclair and Ham 2000; Rawat 1995) while livestock also constitute important livelihood sources for some communities (Ives and Messerli 1989; Kaniyal 2003). By contrast, the majority of households in the Darjeeling Hills depend on tea plantations, which in recent decades has often challenged their livelihood security. However, the case studies show that a growing number of tea plantation people are seeking alternative livelihoods due to temporary or permanent closure of some tea estates and shortage of work due to growing population. Without land ownership rights, plantation workers are left with few options to improve their socioeconomic conditions, in spite of an increase in wages in the case of Singell Tea Estate. By contrast, Mineral Spring has been able to sustain its socio-economic conditions due to a diversification of livelihood sources---including organic tea, as a result, in part, of land ownership.

In dealing with the enhanced livelihood options in the hills, Gardner (2002) notes that in western India the growth of the tourism industry has brought increased employment and enhanced the local economy through a blossoming of the hotel and transport industries. Similarly, in the last decade the growth of tourism in Darjeeling District has provided both skilled and unskilled jobs to a growing number of unemployed people in the area, besides creating ancillary jobs in hotels, tourist travel, trekking, transport, etc. In the last three decades, the increasing population and unavailability of work on the tea plantations have compelled many plantation residents to search for new livelihood options. Therefore, many people from the study areas have been absorbed in some public and private sectors, apart from getting different unskilled jobs that give them other livelihood options.

\section{Livelihood Sources \\ Plantation work}

In Singell Tea Estate, tea labor wages constitute the primary livelihood source. A general survey of income sources reveals that $70 \%$ of households are engaged in plantation work. Out of the 40 respondents, the primary income of $75 \%$ comes from plantation work. But, with a drastic cut in the plantation workforce, there is no household having more than two members employed in plantation work.

All workers (tea pickers, cleaners, sprayers, pruners, etc.) on the Singell Tea Estate are paid daily wages of Rs. 44.70/day (plus $4 \mathrm{~kg}$ of rice) which does not provide livelihood security to workers and their dependents. Besides, wages are given irrespective of work experience or permanency of work; benefits enumerated in the Plantation Labour Act (1951) are fringe in nature. Wages are paid according to the number of workdays (usually for 25-26 days), with Saturdays being half-working days and Sundays non-working days.

\section{Tea cultivation/ farming}

After the closure of Mineral Spring Plantation in the late 1960 s, people lost their tea plantation work. In the late 1990s, however, after having acquired 'patta' (official land document) for the 'occupied lands', these erstwhile workers started organic tea farming as one of the livelihood options. And after having learned organic farming under the guidance of the 'Saigon Tea Consultancy', they now pluck from five to $55 \mathrm{~kg}$ leaves per day during peak season (April-July) and from three to 35 per day during the off-season (August-October). Since 1998 the sale of green tea leaves to neighboring tea estates has been fetching each tea cultivator Rs. 24 per $\mathrm{kg}$, of which Rs. $20 / \mathrm{kg}$ is earned in cash; the remaining 4 rupees for every kilogram of tea goes into savings as a Provident Fund. Thus, these small tea cultivators can earn from Rs. 1,000 to Rs. 16,500 per month on the acreage of land. 


\section{Diversified cash crops}

In the late 1990s, Mineral Spring was transformed from a monoculture tea plantation into a revenue village producing diversified cash crops. Today a variety of cash crops such as, ginger, cardamom, broomsticks, and oranges are cultivated in the Mineral Spring area that serve as diversifying livelihood sources for households. For a majority (28\%) of households cash crops, particularly ginger, constitute the chief income source, while for about $50 \%$ it constitutes a secondary or tertiary income source. Although most of these cash crops are seasonal, they fetch good income. A majority of households cultivate about $10 \mathrm{~kg}$ of ginger, followed by cardamom, broomsticks and oranges. By contrast only 15\% of those interviewed in Singell Tea Estate reported having cultivated any cash crop.

\section{Animal husbandry}

In Singell Tea Estate, less than 10\% of household rear livestock as a livelihood diversification option; $2 \%$ of households rear dairy cows and sell 2-3 liters of milk per day, earning Rs.20-30 per day during season. About $7.5 \%$ of the households supplement their income earning by the sale of goats, pigs or poultry items. A pig or goat can fetch from Rs.3000-5000 in the market.

The near absence of livestock in Singell is mainly due to constraints of space. By contrast, about $35 \%$ of the households in Mineral Spring rear some kind of livestock and earn from sale of meat, live animals, milk and animal dung.

\section{Subsistence farming}

Except for one household with land outside the tea plantation, none in Singell Tea Estate report being engaged in subsistence farming, although some households utilize their kitchen garden for planting chilly, peppers and vegetables. In Mineral Spring after receiving 'patta' in the previously tea cultivated land, almost all households cultivate millet, potato, maize and vegetables. With the major income coming from cash crops and tea, subsistence farming may be less prominent. But it has its own significance, for besides providing items for home consumption, it helps help reduce household expenses on food items, thereby helps in savings for the future.

\section{Off-land employment}

In Singell Tea Estate, due to limited job opportunities in tea plantation and an increasing population, many residents seek employment outside. Of the 40 respondents in Singell, about 30\% of the households depend only on off-land employment for their livelihood. On the other hand, $43 \%$ of the household supplement plantation wage earnings from off-land employment. While the educated individuals works in government or small private sectors in nearby Kurseong town, the illiterate and lower qualified do odd jobs like road construction and casual labor, earning Rs.80-120 a day.
In a revenue-village like Dabaipani Division of Mineral Spring, land provides the most important revenue source for the households. Only for $7.5 \%$ of the 40 respondents' off-land jobs constituted primary income sources, while $10 \%$ of respondents work off-land in road construction, private teaching or in the defence forces to supplement their primary income earning. The less reliance on offland employment is due to high profits from cash crops.

\section{Livelihood insecurity}

Since the inception of tea plantation, the workers have been like bonded laborers in the plantation system. They constantly face livelihood insecurity not entirely due to tea planters' strategy but also due their over-dependence on tea plantation. This becomes more evident during bandhs (strikes). Findings from Singell Tea Estate show that since the plantation laborers depend solely on their wages and rations from plantation for their livelihoods, they suffer badly when the tea garden is forced to close during strikes. Increased production, maintenance and labor costs havelead to financial crises that, while affecting the plantation economy, also impacts the plantation community the most due to its over-dependence on labor wage.

One factor that exacerbates the uncertain future on many plantations is the lack of alternative livelihood sources. Since the inception of tea plantations in Darjeeling "there was no communication between the outside country and the barbed wires of the tea gardens, and a competitive, efficiency based economy didn't emerge; the tea gardens remaining as 'enclaves' of lopsided prosperity” (Roy 1965). And so, as gardens close and re-open or are declared "sick gardens", not only casual or seasonal workers but even permanent workers fear for an uncertain future. And as the stories of retrenchment (as on February 2004) trickles on to other gardens, fear for losing the job grips them. On top of that rumours of "secret agreements" between trade unions and management create even more mistrust between the workers and their safe-guarding agents. These incidents further increase the anxiety of the plantation workers and put their socio-economic situation in great uncertainty. The problem gets aggravated by the plantation-linked landslides, soil erosion and contamination as well as receding water levels and, adversely affecting the diversification of livelihood opportunities.

\section{Concluding Observations}

The increasing socio-economic problems in the tea plantations of the Darjeeling Hills in recent years suggest that perhaps there is a need to adopt alternative systems for the management of the various natural and human resources in the region. Changes could begin by facilitating management of local resources by the local community, as has been demonstrated in Mineral Spring. This, in turn, should lead to stewardship of 'commons' like local forest and land by the local communities, as traditionally practiced by the 'Pahari' community of 
western India (Berkes, Gardner and Sinclair 2000). In both Mineral Spring and Singell, the sanction against tree felling led the communities to plant more trees so as not to use forest for their needs. There is an urgent need for livelihood alternatives in order to sustain and improve the socio-economic conditions of the growing population of tea plantation communities in the Darjeeling Hills. This is a great need at the moment, as failure to create more and diverse livelihood opportunities in plantations can lead the people to once again destroy forest and other natural resources available in their vicinity. Therefore, the major challenge is to create a sustainable ecology and at the same time sustainably develop the economic conditions for the communities that depend on the tea plantations. In other words, the challenge for the future is how to meet the basic needs of the community without simultaneously depleting the natural resources (Berkes, Gardner and Sinclair 2000) such as, land, water, forest and so on.

A substantial part of the present paper is derived from Lalit Premlal Tirkey's Masters' Thesis in Natural Resources Management, entitled Tea Plantations in the Darjeeling District, India: Geo-ecological and Socio-economic impacts in Post-Independence Period, Winnipeg, Manitoba, University of Manitoba, Natural Resources Institute, 2005; URL: www.cc.umanitoba. ca/institutes/natural_resources/canadaresearchchair/ thesis/ltirkey\%2omasters\%2othesis\%202005.pdf.

Lalit P. Tirkey is a Lecturer and Director of SelfFinancing Professional Course at St. Joseph's College, Darjeeling. He finished his Masters in Natural Resources Management from the University of Manitoba, Canada. Currently, he is pursuing his Doctoral Studies in Development Economics from the Department of Economics, National Institute of Technology, Silchar, Assam.

Corresponding address: lalittirkey@yahoo.com

Padam Nepal, PhD, is Assistant Professor of Political Science at St. Joseph's College, North Point, Darjeeling. He has participated and presented papers in a number of national and international seminars and conferences, and has published papers in a number of academic journals. He is the author of Environmental Movements in India: Politics of Dynamism and Transformations (New Delhi: Authorspress, 2009) and An Introduction to Politics (Darjeeling: Bimaleswari Publications, 2009). He also has co-edited (with Anup S. Chakraborty) a volume entitled Politics of Culture, Identity and Protest (New Delhi: Authorspress, forthcoming). His research interestsincludehydro-politics, environmentalandgreen political theory, folk and cultural dimensions of politics, micro-politics of development of marginal communities, politics of recognition, and spatial, symbolic and material mediations of social movements. Corresponding address: padamnepal@gmail.com

\section{References}

Bhadra, M., 1992, Women Workers of Tea Plantations in India, New Delhi: Heritage Publishers.

Banerjee, B., 1982, 'Resource utilization of Darjeeling Himalaya and conservation of ecology', Geographical Review of India 44(3):113-117.

Basu, P., 1979, 'Soil erosion \& landslides on Darjeeling Himalayas', Geographical Review of India 41:78-87.

Berkes, F., J.S. Gardner and J.A. Sinclair, 2000, 'Comparative aspects of mountain land resources management and sustainability: Case studies from India and Canada', International Journal of Sustainable Development and World Ecology 7:376390.

Chada, S.K., 1990, Himalayas: Environmental Problem, New Delhi: Ashish Publishing House.

Chettri, N., 2004, 'Questions on agro-ecological sustenance: A case from tea gardens of Darjeeling', Darjeeling Articles, URL: darjelingnews.nt/ darjeling_articles/dr_nakul_chettri.htm (February 4, 2004).

Choudhuri, M.R., 1978, 'The tea industry in India: A diagnostic analysis on its geo-economic aspects', Indian Economic \& Geographic Studies, Delhi: Oxford Book and Stationery Co.

Fareedi, M., S. Khanna and P.D. Lepcha, 200o, Area and Issue Profile of Darjeeling and Sikkim, Darjeeling: IGSSS and RCDC.

Gardner, J.S., 2002, 'Natural hazards risk in the Kullu District, Himachal Pradesh, India', The Geographical Review 92(2):282-306.

Heimsath, M.A., 2000, Himalayan Erosion, URL: www. india-seminar.com/200o/486\%//20oheisath.com (April 27, 2004).

ICIMOD, 2003, Policy Advocacy for Enhancing Equity and Rights in the Management of Common Property Resources in the Hindu Kush Himalayas, Kathmandu: International Center for Integrated Mountain Development (ICIMOD).

Ives, J.D., \& Messerli, 1989, The Himalayan Dilemma: Reconciling Development and Conservation, London: Routledge.

Kaniyal, J.S., 2003, 'Regional imbalances and sustainable crop farming in the Himachal Himalaya, India', Ecological Economics 48:419-435.

Moitra, M.C., 1991, New Dimensions of TEA: Its Projection in the 21st Century, Calcutta: Printpack Offset.

Nepal, P., 2011, 'Right to water qua vadis: Interrogating hydropolitics in Darjeeling', a paper presented at the UGC and ICSSR-sponsored national seminar on 'Environment Security and Human Rights', November 11, 2011, Sikkim University, Department of Law and Legal Jurisprudence.

Nusser, M., 2000, 'Changeand persistence: Contemporary 
landscape transformation in the Nanga Parbat Region, Northern Pakistan', Mountain Research and Development 20(4):348-355.

O’Malley, L.S.S., 1907, Darjeeling: Bengal District Gazetteers, New Delhi: Logos Press.

Pant, R. and R. Khanduri, 1998, 'Ecological degradation due to exploitation of natural resources and development', The Cultural Dimension of Ecology 18:37-51.

Rai, C.B. and R.L. Sarkar, 1986, Development of Human Resources in Darjeeling Hills: Case Study of the Impact of the Hayden Hall Programmes on the Weaker Sections of Population, Darjeeling: Indian Institute of Hill Economy.

Raina, J.L., 1992, Himalayan Environment, Man and the Economic Activities-Part II, Jaipur: Pointer Publishers.

RCDC, 1996, Concept Paper, Darjeeling: RCDC.

Rawat, A.S., 1995, 'Deforestation and forest policy in the Lesser Himalaya Kumaun: Impact on peasant women and tribal populations, Mountain Research and Development 15(4):311-322.

Roy, H., 1965, Tea Price Stabilization: The Indian Case, Calcutta: World Press.

Sarkar, F.L. and M.P. Lama, 1986, The Eastern
Himalayas: Environment and Economy, Delhi: Atma Ram \& Sons.

Sarkar, F.L. and M.P. Lama, 1986, Tea Plantation Workers in the Eastern Himalayas: A Study on Wages, Employment and Living Standards, Delhi: Atma Ram \& Sons.

Schickhoff, U., 1995, 'Himalayan forest-cover changes in historical perspective: A case study in the Kaghan Valley, Northern Pakistan', Mountain Research and Development 15(1):3-18.

Sinclair, J. and L. Ham, 200o, 'Household adaptive strategies: Shaping livelihood security in the western Himalaya', Canadian Journal of Development Studies 21(1):89-110.

Starkel, L., 1993, 'The effects of deforestation on slopes and channel evolution in the tectonically active Darjeeling Himalaya', Earth Surface Processes and Landforms 18:167-186.

Starkel, L. and S. Basu, 2000, Rains, Landslides and Floods in the Darjeeling Himalayas, New Delhi: Indian National Science Academy.

Tiwari, P.C., 2000, 'Land use changes in Himalaya and their impact on the plains ecosystem: Need for sustainable land use, Land Use Policy 17:101-111.

\section{CALENDAR OF EVENTS - WATER}

2-6 February. 2012, 2nd Asia Water Summit, (Conference/Symposia) Location: Bangkok, Thailand. Organized by ICIMOD. More Info: www. icimod.org.

9-11 February, 2012: 9th EverythingAboutWater EXPO2012:InternationalExhibitionandConference on Water and Wastewater Management. Location: New Delhi, India. Contact Email: intlenquiry@ eawater.com. More info: www.eawater.com/expo.

14-15 February, 2012: National Seminar on Governance and Management of Drinking Water: Issues and Challenges. Location: Hyderabad, Andhra Pradesh, India. More info: www.ipeindia. org.

24 February, 2012: 7th Annual Water Symposium. Location: Sydney, NSW, Australia. More info: www. legalwiseseminars.com.au/7th-annual-watersymposium\&campaign=111031_ECONF.

26-29 February, 2012, IWA Specialty Conference: Water Loss 2012, Location: Manila, Philippines. Contact Email: www.2012committee@iwawaterloss.org. More info: www.iwa-waterloss. org/2012/.

12-17 March, 2012: 6 th World water forum: Solutions for Water. Location: Marseille, France. More info: www.worldwaterforum6.org.
10-14 April, 2012: India Water Week. Location: New Delhi, India. Contact Email: indiawaterweek@ yahoo.in. More info: www.mowr.nic.in/iww.

16-17 April, 2012: Smart Water Systems. Location: Copthorne Tara Hotel, London, United Kingdom. Moreinfo:www.smi-online.co.uk/events/overview. asp ?is $=17 \&$ ref $=3698$.

25-27 April, 2012: 1st International Conference on the Design, Construction, Maintenance, Monitoring and Control of Urban Water Systems. Location: New Forest, United Kingdom. More info: www. wessex.ac.uk/12-conferences/urban-water-2012. html.

7 -10 May, 2012: Sixteenth International Water Technology Conference (IWTC 16). Location: Istanbul, Turkey. More info: www.iwtc.info.

4-6 July, 2012: 6th International Conference on Waste Management and the Environment. Location: New Forest, United Kingdom. More info: www.wessex. ac.uk/12-conferences/waste-management-2012/ page-2.html.

23-27 September, 2012: 11th International Drainage Workshop (IDW). Location: Cairo, Egypt. Contact Email: encid@link.com.eg. More info: www.encid. org.eg. 